\title{
THE FIRST GLYPTOSTROBOXYLON AND TAXODIOXYLON DESCRIPTIONS FROM THE LATE MIOCENE OF TURKEY AND PALAEOCLIMATOLOGICAL EVALUATION
}

\author{
ÜNAL AKKEMIK ${ }^{1, *}$, NEVRIYE NESLIHAN ACARCA BAYAM ${ }^{2}$ \\ 'Istanbul University-Cerrahpasa, Facult y of Forestry, Department of Forest Botany, Bahçeköy-Sarıyer, İstanbul, Turkey; \\ e-mail: uakkemik@istanbul.edu.tr. \\ ${ }^{2}$ Çapa Science College, Çapa-İstanbul, Turkey. \\ ${ }^{*}$ corresponding author
}

Akkemik, Ü., Acarca Bayam, N. N. (2019): The first Glyptostroboxylon and Taxodioxylon descriptions from the late Miocene of Turkey. - Fossil Imprint, 75(2): 268-280, Praha. ISSN 2533-4050 (print), ISSN 2533-4069 (on-line).

\begin{abstract}
Taxodioxylon HARTIG (emended by Gothan 1905) was widely described from the late Oligocene of the European part of Turkey (Thrace) and the early Miocene of greater Turkey, Anatolia. Glyptostroboxylon Conw. was also described from the early Miocene of central Anatolia. The purpose of this paper is to present a more detailed extended history of these two genera up to the late Miocene (Tortonian) with new descriptions from the Galatean Volcanic Province in central Turkey. The wood identification showed the presence of two fossil species; Glyptostroboxylon rudolphii Dolezych et BurGH and Taxodioxylon gypsaceum (Göpp.) Greguss. In conclusion, the swamp and lowland warm-temperate forest composition including Glyptostroboxylon and Taxodioxylon in the Galatean Volcanic Province, continued from the early Miocene (Burdigalian) to the late Miocene (Tortonian).
\end{abstract}

Key words: Galatean Volcanic Province, Glyptostroboxylon rudolphii, late Miocene, petrified forest, Taxodioxylon gypsaceum, swamp forest

Received: December 18, 2018 | Accepted: March 11, 2019 | Issued: November 25, 2019

\section{Introduction}

Turkey had four volcanic provinces during the Miocene. One of them was the Galatean Volcanic Province (GVP) (or Köroglu Volcanics) (Text-fig. 1), which covered an area of approximately $12,800 \mathrm{~km}^{2}$ in central Anatolia (Toprak et al. 1996, Koçyiğit et al. 2003, Kazancı 2012). Koçyiğit et al. (2003) identified three major volcanic phases. They were (1) the late Campanian - Lutetian subductional phase; (2) the post-Lutetian collisional phase and (3) the Oligocene - Miocene post collisional phase. The most (significant) palaeobotanical studies were performed on remains from the Miocene. Keller et al. (1992), Toprak et al. (1996), Wilson et al. (1997) and Adiyaman et al. (2001) all stated that two distinct phases of volcanism occurred in the Miocene of the GVP, in the early Miocene (24-17 Ma) and in the late Miocene (9-10 Ma). Several petrified wood descriptions were reported from the early Miocene of the west GVP (Akkemik et al. 2009, 2016, 2017, Bayam et al. 2018). However, there is no information related to the late Miocene of the east GVP with respect to petrified woods.

Sequoioxylon gypsaceum (GöPP.) GrEGUSs was described for the first time by Özgüven-Ertan (1983) from Beypazar1-Ankara (Turkey), located on the southern border of the GVP. The location where this species was originally found was dated as Pliocene (Özgüven-Ertan 1983). There are other petrified woods from the GVP (Akkemik et al. 2009, 2016, 2017, Bayam et al. 2018) of Burdigalian (early Miocene) age. Sequoioxylon R.E.TorR. and Taxodioxylon HARTiG (Akkemik et al. 2009), and Glyptostroboxylon Conw. (Akkemik et al. 2017) were identified in the central GVP from the middle - late Burdigalian. A forest structure composed of Palmoxylon sp. possible wood of Trachycarpus H.Wendl. (Iamandei et al. 2018), Salix L./Populus L., Liquidambar L., Quercus L. section Ilex, Juniperus L., Acer L., Cedrus Trew. and Picea A.Dietr., Ulmus L. and Pinus L. (Akkemik et al. 2016) was identified in the western GVP with an age of early - middle Burdigalian. Recently, Bayam et al. (2018) added Podocarpus L'Hér. ex Pers., Fraxinus L. and Zelkova Spach to the forest composition in the western GVP. Concerning the description of the Podocarpus wood in the western GVP, there is also a possibility that a "podocarpoid" wood, attributed to the fossil genus Podocarpoxylon GoTHAN, represents another extinct type, e.g. wood of Doliostrobus MARION can in principle be labelled as Podocarpoxylon helmstedtianum H.GoTTWALD (see Sakala 2011). 
Other types of remains such as leaves, cones and fruits from Güvem in the central GVP were initially identified by Kasapligil (1977), and subsequently by Denk et al. (2017b), who re-analysed the macrofossils and identified more than 40 species. By using pollen data, Yavuz-Işık and Demirci (2009) identified a vegetation assemblage composed of Pinaceae, Ulmus, Salix, Quercus, Carpinus L., Carya NutT. and Engelhardia Lesch. ex Blume in the central GVP. Furthermore, the Miocene palynoflora of central Anatolia was determined by palynological studies (Karayiğit et al. 1999, Akgün et al. 2002, 2007, Kayseri and Akgün 2008, Yavuz-Iş1k 2008). Although the Oligocene and early Miocene forest vegetation of the western and central GVP has been studied in detail (Kasapligil 1977, Akkemik et al. 2009, 2016, Yavuz-Iş1k and Demirci 2009, Denk et al. 2017b, Bayam et al. 2018), there is still a gap in the wood flora from the late Miocene of the eastern GVP. The purpose of this study is to describe some new fossil conifer woods from the late Miocene of the eastern GVP, and to evaluate the results with respect to palaeoclimate.

\section{Geological setting}

The study area is located in the eastern GVP, near the village of Sakarcaören near to the town of Orta, Çankırı province (Text-fig. 1). Its latitude and longitude coordinates are $40^{\circ} 36^{\prime} 42.46^{\prime \prime} \mathrm{N}$ and $33^{\circ} 9^{\prime} 16.14^{\prime \prime} \mathrm{E}$. The current altitude of the site is $1,340 \mathrm{~m}$. The fossil site is described in the geology map numbered Çankırı - G30 (Sevin and Uğuz 2011). Sengüler (2007) studied the geological setting of the area in detail (Text-fig. 2). The fossil site is situated in the Hüyükköy Formation. The Hançili Formation from the early Miocene lies under the Hüyükköy Formation (Text-fig. 2). The Hüyükköy

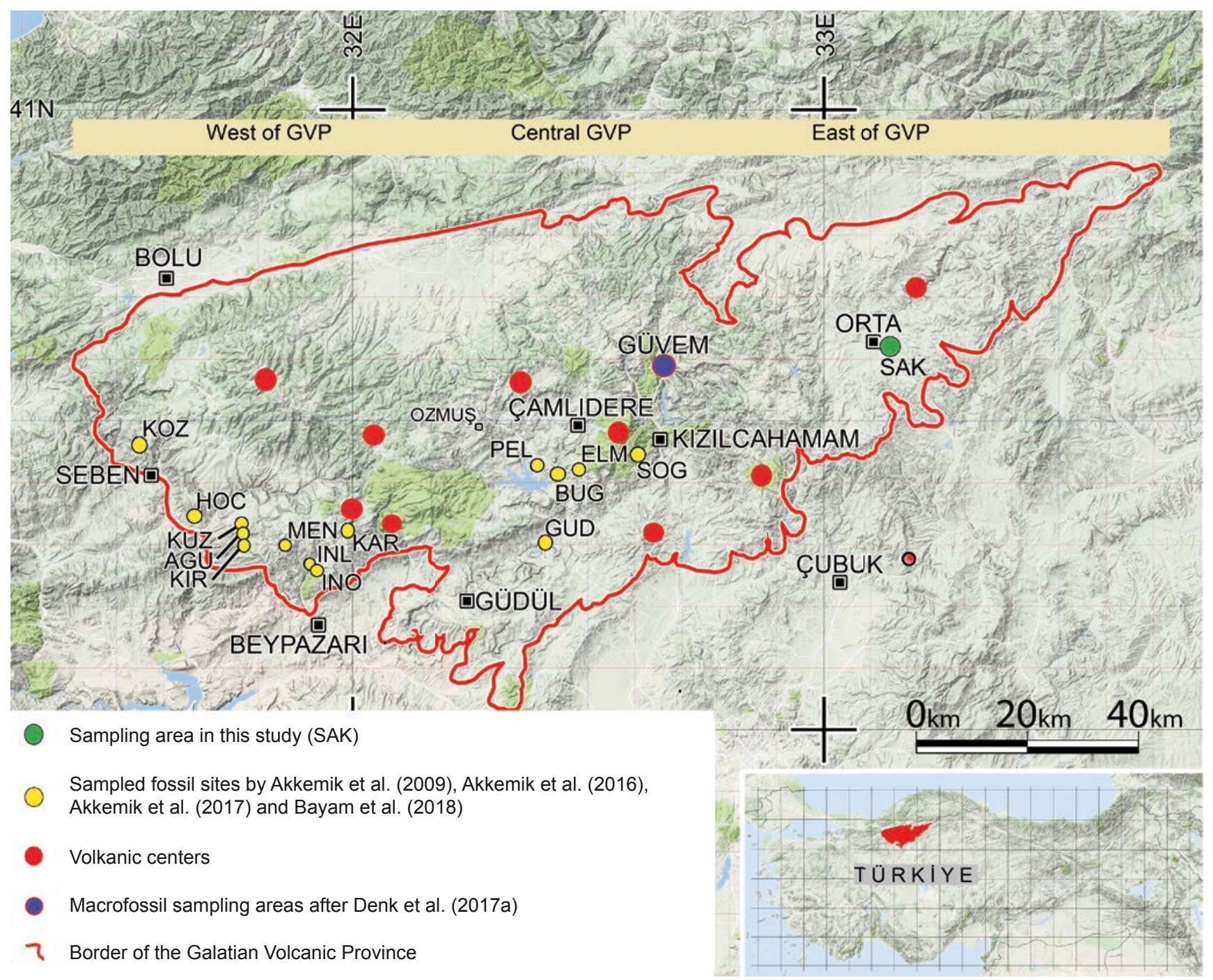

Text-fig. 1. Sampling areas in Çankırı province: the village of Sakarcaören near to the town of Orta (green circle) in the east of GVP, and the other sites (yellow circles), volcanic centers (red circles) and the border of GVP. The sites marked as yellow circles: ELM, EImali village; SOG, Soguksu National Park; BUG, Bugralar village; INO, Inozu Valley South Side; INL, Inozu Valley North Side; KAR, Karasar village; MEN, Menceler Plateau; KIR, Kiraluc Site near Nuhhoca village; AGU, Asagiguney village; KUZ, Kuzca village (Bayam et al. 2018); PEL, Pelitcik village (Akkemik et al. 2009); GUD, Gudul (Akkemik et al. 2017); HOC, Hoçaş village and KOZ, Kozyaka village (Akkemik et al. 2016). The sites located in the western part (INO, INL, KAR, MEN, KIR, AGU, KUZ, HOC and KUZ) are from early - middle Burdigalian and Hancili Formation (Altun et al. 2002, Akbaş et al. 2002). The sites in the central part (GUD, BUG, ELM, PEL and SOG) are from middle - late Burdigalian, Pazar Formation (Kazancı 2012, Sen et al. 2017), and finally the fossil site in the east part of GVP is the late Miocene, Hüyükköy Formation (Sengüler 2007). 


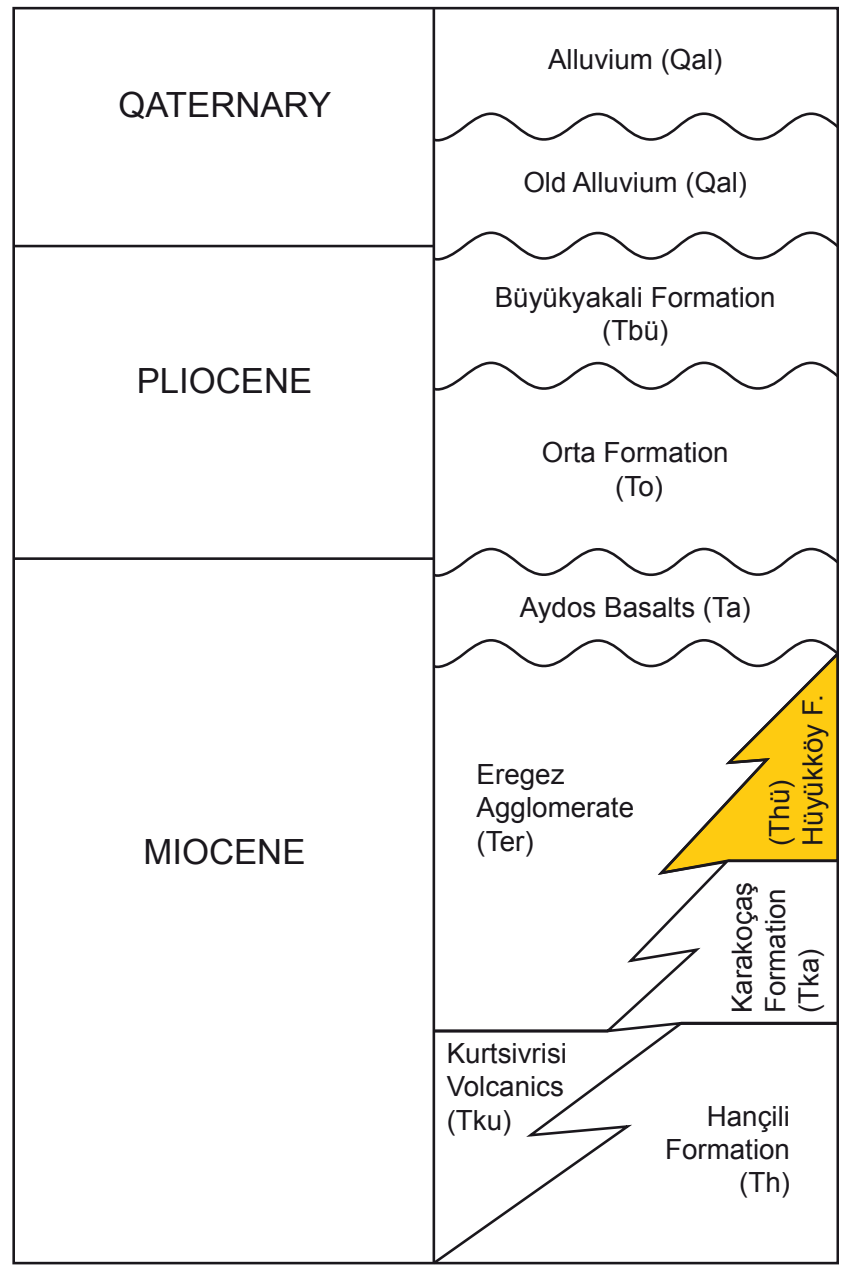

Text-fig. 2. Generalised stratigraphy of the area including the fossil site in Orta-Şabanözü (Sengüler 2007). The coloured formation is Hüyükköy Formation, aged as late Miocene and containing fossil woods.

Formation is described as having an abundance of fossil remains and petrified woods and can be differentiated from the other formations with the same remains (Sengüler 2007). This formation has yellow, dirty white and grey claystone, sandstone and marl layers. Palynological studies of the peats suggested the age to be late Miocene - Pliocene (Türkecan et al. 1991, Sengüler 2007). Türkecan et al. (1991) also stated that the Hüyükköy Formation was deposited in a fresh water lake or mild brackish lake environment based on the presence of peats, silicified trees and other fossil plant remains. Based on the fossil specimens taken from the level of the lacustrine limestone lying over the peat, the Hüyükköy Formation was confirmed as late Miocene (Türkecan et al. 1991).

\section{Material and methods}

The petrified wood pieces are small and distributed throughout the field site (Text-fig. 3). A total of 21 petrified wood samples were collected from the area of size: height $7-28 \mathrm{~cm}$, width $2-8.5 \mathrm{~cm}$ and length $1.5-25 \mathrm{~cm}$.

The petrified wood samples were coded as SAK01 to SAK21 using the first three letters of the site name. All samples are deposited in the Wood Anatomy Laboratory

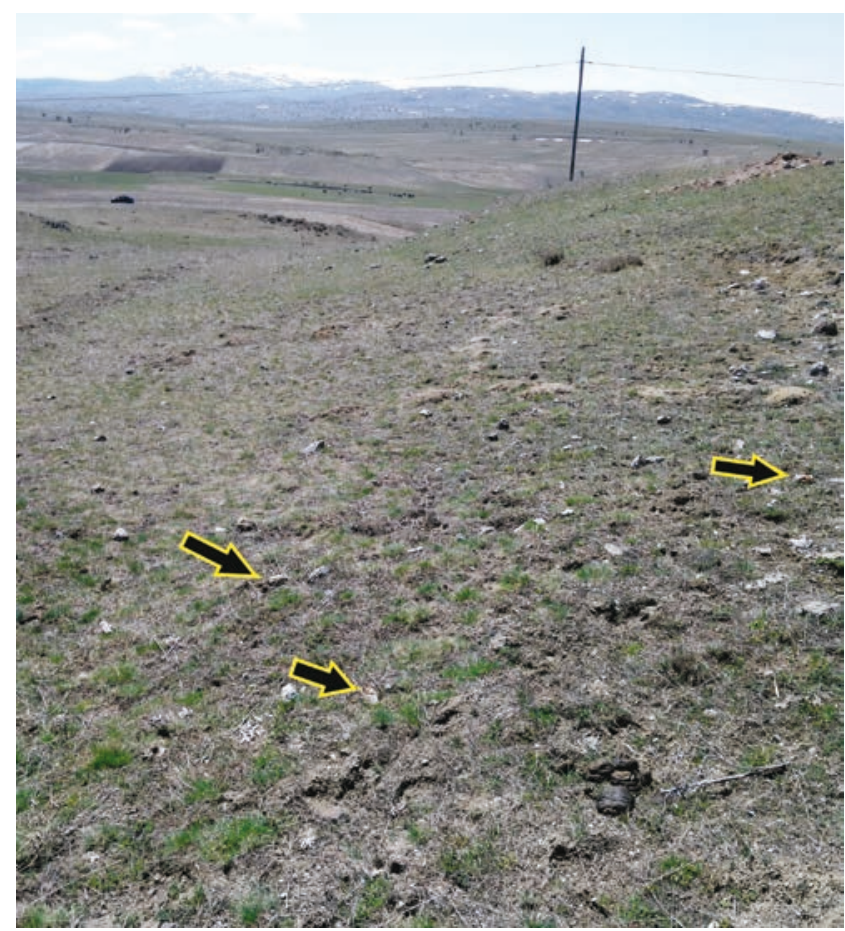

Text-fig. 3. Photo of the area where the fossil samples were collected. It is near to Sakarcaören village in the city of Orta, Çankırı Province. Arrows indicate the petrified wood pieces.

of the Forest Botany Department, Faculty of Forestry at Istanbul University.

The samples were separated into two groups based on their macroscopic features visible under binocular microscope. Macroscopically the woods could be separated into two groups: (1) growth ring boundaries distinct, transition from earlywood to latewood mostly abrupt, and (2) growth ring boundaries indistinct, transition from earlywood to latewood gradual. Four of the samples, two from each group (SAK12 and SAK15 from group 1; SAK 14 and SAK18 from group 2 ), were selected for three thin plane sections (transverse section, TS, radial longitudinal section, RLS, and tangential longitudinal section, TLS). Wood identification was carried out using transmitted light microscopy. In the analysis, we followed the terminology and guidelines of the IAWA Committee (2004) for softwood identification. The related references (e.g. Barefoot and Hankins 1982, Tidwell 1998, Fairon-Demaret et al. 2003, Akkemik et al. 2005, 2009, 2016, 2017, Vassio et al. 2008, Wheeler 2011, Uhl et al. 2014, Pujana and Ruiz 2017) and microslides of extant woods accompanied by herbarium vouchered specimens housed in the Forest Botany Department of the Faculty of Forestry, Istanbul University, were used in identification and comparisons.

\section{Systematic palaeobotany}

Order Cupressales Link, 1829

Family Cupressaceae Gray, 1822 nom. cons.

\section{Genus Glyptostroboxylon Conw., 1885}

\section{Glyptostroboxylon rudolphii DoLezych et BuRGH, 2004}

Studied material. SAK14 and SAK18 (Repository: Fossil collection of the Department of Forest 
Botany, Faculty of Forestry, Istanbul University, Istanbul, Turkey).

H o r i z o n . Hüyükköy Formation.

A g e. Late Miocene (Tortonian).

L o c a lity. Çankırı: The village of Sakarcaören near to the town of Orta (latitude and longitude coordinates are $40^{\circ} 36^{\prime} 42.46^{\prime \prime} \mathrm{N}$ and $\left.33^{\circ} 9^{\prime} 16.14^{\prime \prime} \mathrm{E}\right)$.

$\mathrm{D}$ e s c r i p t i o $\mathrm{n}$. The studied specimen sizes are: height $7.5-8.5 \mathrm{~cm}$, width $4.5-7 \mathrm{~cm}$ and lengths $2.5-4 \mathrm{~cm}$ in SAK14 and SAK18, respectively. The microscopic description of the woods is given below:

Transverse Section (TS): Annual rings are $0.25-1 \mathrm{~mm}$, with indistinct boundaries marked by only 1-2 rows of radially flattened latewood tracheids. Earlywood/latewood transition gradual, and no direct transition from earlywood to latewood was observed. No resin canals were observed. Tracheids are usually polygonal (Pl. 1, Fig. 1). The tangential and radial diameters of the tracheids are $37(21-47) \mu \mathrm{m}$ and $44(24-63)$ $\mu \mathrm{m}$ in the early part of the earlywood and $34(22-49) \mu \mathrm{m}$ and 21 (7-36) $\mu \mathrm{m}$ respectively, in the final rows of latewood. Double wall thickness is $5(1-10) \mu \mathrm{m}$ in earlywood and $6(4-9) \mu \mathrm{m}$ in latewood (Tab. 1). The number of tracheids between two rays is $2-14$. Axial parenchyma abundant, and diffuse.

Tangential Longitudinal Section (TLS): Rays are uniseriate ( $\mathrm{Pl}$. 1, Fig. 2, right), and very rarely partly biseriate (Pl. 1, Fig. 2), cells very low $1-4(-7)$ in height (Pl. 1, Fig. 2). Ray width is 18 (12-23) $\mu \mathrm{m}$ and height is 53 (21-121) $\mu \mathrm{m}$ (Tab. 1). Axial parenchyma cells have thin smooth transverse walls (P1. 1, Fig. 3).

Radial Longitudinal Section (RLS): Rays are homogeneous. Tracheidal pits small in diameter, and in 1-3 horizontal rows (Pl. 1, Fig. 4). No helical thickenings observed, and crassulae only slightly visible. Cross- field pits mostly with significantly reduced border, i.e. "glyptostroboid" (similar to pinoid as in IAWA Committee 2004) and sometimes taxodioid, with 2-3 (1-4) pits per cross-field, and arranged in 1-2 rows, regular or more often irregular (Pl. 1, Figs 5, 6).

Comparison. According to the emended diagnosis given by Dolezych and Van der Burgh (2004), Glyptostroboxylon has clear growth rings having wider tracheids in earlywood than in latewood, 1-3(-4) rows of tracheidal pitting, axial parenchyma smooth to moderately thick with pitted end walls, homogeneous rays and predominantly glyptostroboid, also cupressoid and taxodioid type of cross-field pits. In the wood studied here, growth ring borders are visible, cross-field pits are predominantly glyptostroboid, (sometimes taxodioid), and ray height is relatively low. As it has very similar features to Glyptostroboxylon, we attributed the wood to this fossil genus. Sequoioxylon and Taxodioxylon are the other similar genera. In Sequoioxylon and Taxodioxylon, annual ring borders are clearly distinct, cross-field pits are predominantly taxodioid and often arranged in one horizontal row, ray heights are variable but generally much higher than in Glyptostroboxylon (Süss and Velitzelos 1997, Dolezych and Van der Burgh 2004, Teodoridis and Sakala 2008, Akkemik et al. 2009, 2017, Koutecký and Sakala 2015). Recently, Akkemik et al. (2017) identified Glyptostroboxylon from the middle - late Burdigalian (early Miocene) from the central area of the GVP. Kasapligil (1977) and Denk et al. (2017b) collected leaf and cone fossils of this genus from the early Miocene fields of the Güvem area. The present description is from the late Miocene (Tortonian) of the eastern GVP.

Two fossil-species of Glyptostroboxylon were described as Glyptostroboxylon tenerum (KRAUs) Conw. and Glyptostroboxylon rudolphii Dolezych et BuRGH (Text-fig. 4).

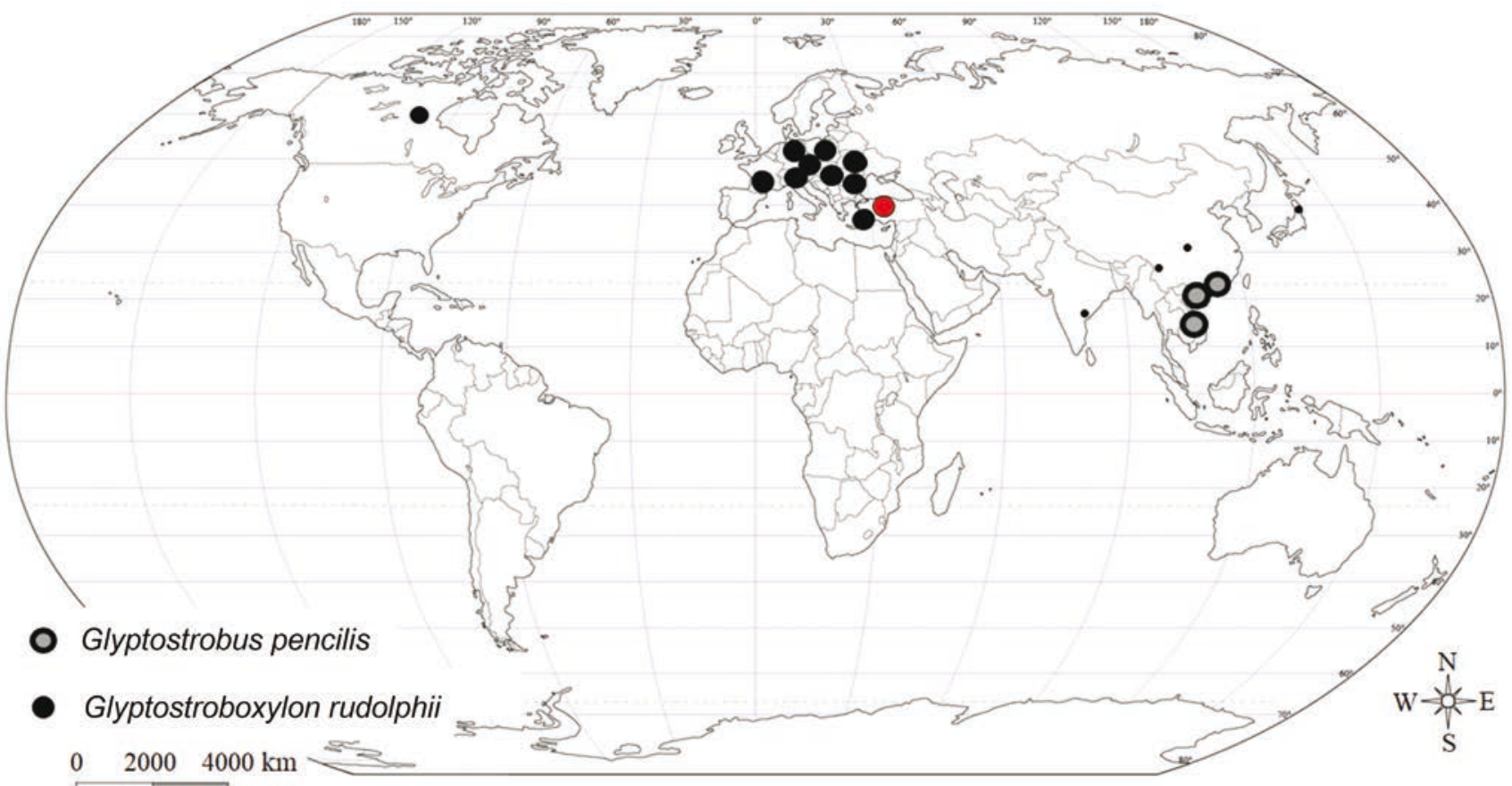

Text-fig. 4. Distribution of Glyptostroboxylon rudolphii in the Miocene (solid circles) and Glyptostrobus pensilis at present (open circles). It grows in the subtropical swamps of Vietnamese and China (Eckenwalder 2009, Farjon 2010). 
Table 1. Tracheid dimensions and ray features of the samples.

\begin{tabular}{|c|c|c|c|c|c|c|c|c|}
\hline \multirow[b]{2}{*}{ Sample } & \multicolumn{6}{|c|}{ Tracheids } & \multicolumn{2}{|c|}{ Rays } \\
\hline & $\begin{array}{c}\text { Tangential } \\
\text { diameter in } \\
\text { earlywood } \\
(\mu \mathrm{m})\end{array}$ & $\begin{array}{c}\text { Radial } \\
\text { diameter in } \\
\text { earlywood } \\
(\mu \mathrm{m})\end{array}$ & $\begin{array}{c}\text { Wall } \\
\text { thickness in } \\
\text { earlywood } \\
(\mu \mathrm{m})\end{array}$ & $\begin{array}{c}\text { Tangential } \\
\text { diameter in } \\
\text { latewood } \\
(\mu \mathrm{m})\end{array}$ & $\begin{array}{c}\text { Radial } \\
\text { diameter in } \\
\text { latewood } \\
(\mu \mathrm{m})\end{array}$ & $\begin{array}{c}\text { Wall } \\
\text { thickness in } \\
\text { latewood } \\
(\mu \mathrm{m})\end{array}$ & $\begin{array}{l}\text { Height } \\
(\mu \mathrm{m})\end{array}$ & $\begin{array}{l}\text { Width } \\
(\mu \mathrm{m})\end{array}$ \\
\hline \multicolumn{9}{|c|}{ Glyptostroboxylon } \\
\hline SAK14 & $\begin{array}{c}40 \\
(32-44) \\
\end{array}$ & $\begin{array}{c}44 \\
(28-57) \\
\end{array}$ & $\begin{array}{c}4 \\
(1-6) \\
\end{array}$ & $\begin{array}{c}37 \\
(29-41) \\
\end{array}$ & $\begin{array}{c}28 \\
(22-36) \\
\end{array}$ & $\begin{array}{c}6 \\
(4-8) \\
\end{array}$ & $\begin{array}{c}66 \\
(29-121) \\
\end{array}$ & $\begin{array}{c}18 \\
(12-23) \\
\end{array}$ \\
\hline SAK18 & $\begin{array}{c}34 \\
(21-47) \\
\end{array}$ & $\begin{array}{c}44 \\
(24-63) \\
\end{array}$ & $\begin{array}{c}5 \\
(2-10) \\
\end{array}$ & $\begin{array}{c}31 \\
(22-49) \\
\end{array}$ & $\begin{array}{c}14 \\
(7-24) \\
\end{array}$ & $\begin{array}{c}6 \\
(4-9) \\
\end{array}$ & $\begin{array}{c}37 \\
(21-75) \\
\end{array}$ & $\begin{array}{c}17 \\
(14-22) \\
\end{array}$ \\
\hline Average & $\begin{array}{c}37 \\
(21-47)\end{array}$ & $\begin{array}{c}44 \\
(24-63) \\
\end{array}$ & $\begin{array}{c}4.5 \\
(1-10)\end{array}$ & $\begin{array}{c}34 \\
(22-49) \\
\end{array}$ & $\begin{array}{c}21 \\
(7-36)\end{array}$ & $\begin{array}{c}6 \\
(4-9) \\
\end{array}$ & $\begin{array}{c}53 \\
(21-121)\end{array}$ & $\begin{array}{c}17.5 \\
(12-23)\end{array}$ \\
\hline \multicolumn{9}{|c|}{ Sequoioxylon } \\
\hline SAK12 & $\begin{array}{c}38 \\
(19-53)\end{array}$ & $\begin{array}{c}31 \\
(18-44)\end{array}$ & $\begin{array}{c}6 \\
(2-10)\end{array}$ & $\begin{array}{c}27 \\
(19-34) \\
\end{array}$ & $\begin{array}{c}10 \\
(4-22)\end{array}$ & $\begin{array}{c}8 \\
(5-12) \\
\end{array}$ & $\begin{array}{c}110 \\
(52-212)\end{array}$ & $\begin{array}{c}10 \\
(7-15)\end{array}$ \\
\hline SAK15 & $\begin{array}{c}32 \\
(24-38) \\
\end{array}$ & $\begin{array}{c}42 \\
(25-58) \\
\end{array}$ & $\begin{array}{c}5 \\
(2-8)\end{array}$ & $\begin{array}{c}24 \\
(15-32) \\
\end{array}$ & $\begin{array}{c}9 \\
(4-13)\end{array}$ & $\begin{array}{c}8 \\
(3-12)\end{array}$ & $\begin{array}{c}138 \\
(20-507)\end{array}$ & $\begin{array}{c}13 \\
(11-17)\end{array}$ \\
\hline Average & $\begin{array}{c}35 \\
(19-53)\end{array}$ & $\begin{array}{c}37 \\
(18-58)\end{array}$ & $\begin{array}{c}6 \\
(2-10)\end{array}$ & $\begin{array}{c}26 \\
(15-34)\end{array}$ & $\begin{array}{c}10 \\
(4-22)\end{array}$ & $\begin{array}{c}8 \\
(3-12)\end{array}$ & $\begin{array}{c}124 \\
(20-507)\end{array}$ & $\begin{array}{c}12 \\
(7-17)\end{array}$ \\
\hline
\end{tabular}

The main differences between these two fossil-species are in the pitting on the tracheid radial walls. If the pits are biseriate with crassulae, the wood is evaluated as $G$. rudolphii. In contrast, wood having uniseriate pits on the tracheid radial wall but without crassulae, is accepted as G. tenerum (Dolezych and Van der Burgh 2004, Teodoridis and Sakala 2008). Because tracheid pitting can be up to 3 vertical rows and abundant, cross-field pits are generally 1-4 predominantly glyptostroboid but also taxodioid types, our woods are identified as Glyptostroboxylon rudolphii.

Dolezych and Van der Burgh (2004), Teodoridis and Sakala (2008) and Dolezych (2011) explained that two species of Glyptostroboxylon are represented by two different genera. Glyptostroboxylon tenerum (KRAUS) Conw. is represented by modern Cunninghamia R.BR. in Rich., and Glyptostroboxylon rudolphii Dolezych et Burgh by modern Glyptostrobus. The modern Glyptostrobus has only one species (G. pensilis K.Косн) growing in the swamp forests of Vietnam and China (Eckenwalder 2009, Farjon 2010; Text-fig. 4).

\section{Genus Taxodioxylon HaRTIG, 1848 \\ (emended by Gothan 1905)}

\section{Taxodioxylon gypsaceum (GöPP.) KRÄUSEL, 1949}

Studied material. SAK12 and SAK15 (Repository: Fossil collection of the Department of Forest Botany, Faculty of Forestry, Istanbul University, Istanbul, Turkey).

H o r i z o n . Hüyükköy Formation.

A g e. Late Miocene (Tortonian).

L o c a l i t y. Çankırı: The village of Sakarcaören near to the town of Orta (latitude and longitude are $40^{\circ} 36^{\prime} 42.46^{\prime \prime} \mathrm{N}$ and $\left.33^{\circ} 9^{\prime} 16.14^{\prime \prime} \mathrm{E}\right)$.

Description. The sizes of the studied specimens are: height $13.5-15.5 \mathrm{~cm}$, width $6.5-14 \mathrm{~cm}$, and length $2.5-$ $4.5 \mathrm{~cm}$ in SAK12 and SAK15, respectively. Microscopic description of the woods is given below.
Transverse Section (TS): Growth rings $0.5-3.0 \mathrm{~mm}$ in width, with distinct boundaries marked by $2-13$ rows of thickwalled latewood tracheids. Latewood distinctive, earlywood/ latewood transition gradual or abrupt. No resin canals were observed. Tangential and radial diameters of tracheids are $35(19-53) \mu \mathrm{m}$ and $37(18-58) \mu \mathrm{m}$ in earlywood and 26 (15-34) $\mu \mathrm{m}$ and 10 (4-22) $\mu \mathrm{m}$ respectively, in latewood. Double wall thickness is $6(2-10) \mu \mathrm{m}$ in earlywood and 8 (3-12) $\mu \mathrm{m}$ in latewood, respectively (Tab. 1). The number of tracheids between two rays is $2-14$. Axial parenchyma abundant, diffuse, and seen in the latewood zone or in the transition to latewood area (Pl. 2, Figs 1, 2).

Tangential Longitudinal Section (TLS): Rays are uniseriate. Ray width is $12(7-17) \mu \mathrm{m}$ and height is $2-32$ (mostly 5-14) cells, and 124 (20-507) $\mu \mathrm{m}$ (Tab. 1; Pl. 2, Fig. 3). Transverse walls of axial parenchyma cells are smooth and slightly nodular (Pl. 2, Figs 4, 5).

Radial Longitudinal Section (RLS): Tracheidal pitting is $1-2(-3)$ seriate on the radial surface of tracheids (Pl. 2, Figs 7, 9). Crassulae slightly visible (Pl. 2, Fig. 7). Horizontal and end walls of rays are smooth (Pl. 2, Fig. 6). Cross-field pits are taxodioid and 1-6 pits in one horizontal row per cross-field (Pl. 2, Fig. 8).

Comparison. The studied woods show a clear latewood zone, gradual to abrupt transition from earlywood to latewood, smooth transverse walls of axial parenchyma cells and 1-3 rows of tracheid pits. We consider them as taxodioid wood. Anatomical features of the specimens are rather similar to Sequoioxylon from Turkey (Özgüven-Ertan 1983, Akkemik et al. 2005, 2009, 2017, 2019, Akkemik and Sakınç 2013), and Taxodioxylon from Turkey (Akkemik et al. 2009).

Regarding fossil species of Sequoioxylon and Taxodioxylon, many studies were carried out on these species (e.g. Greguss 1967, Özgüven-Ertan 1971, 1983, Yang and Zheng 2003, Erdei et al. 2009, Blokhina et al. 2010, Dolezych 2011, Iamandei et al. 2013, Koutecký and Sakala 2015, Tian et al. 2018) (Text-fig. 5). 


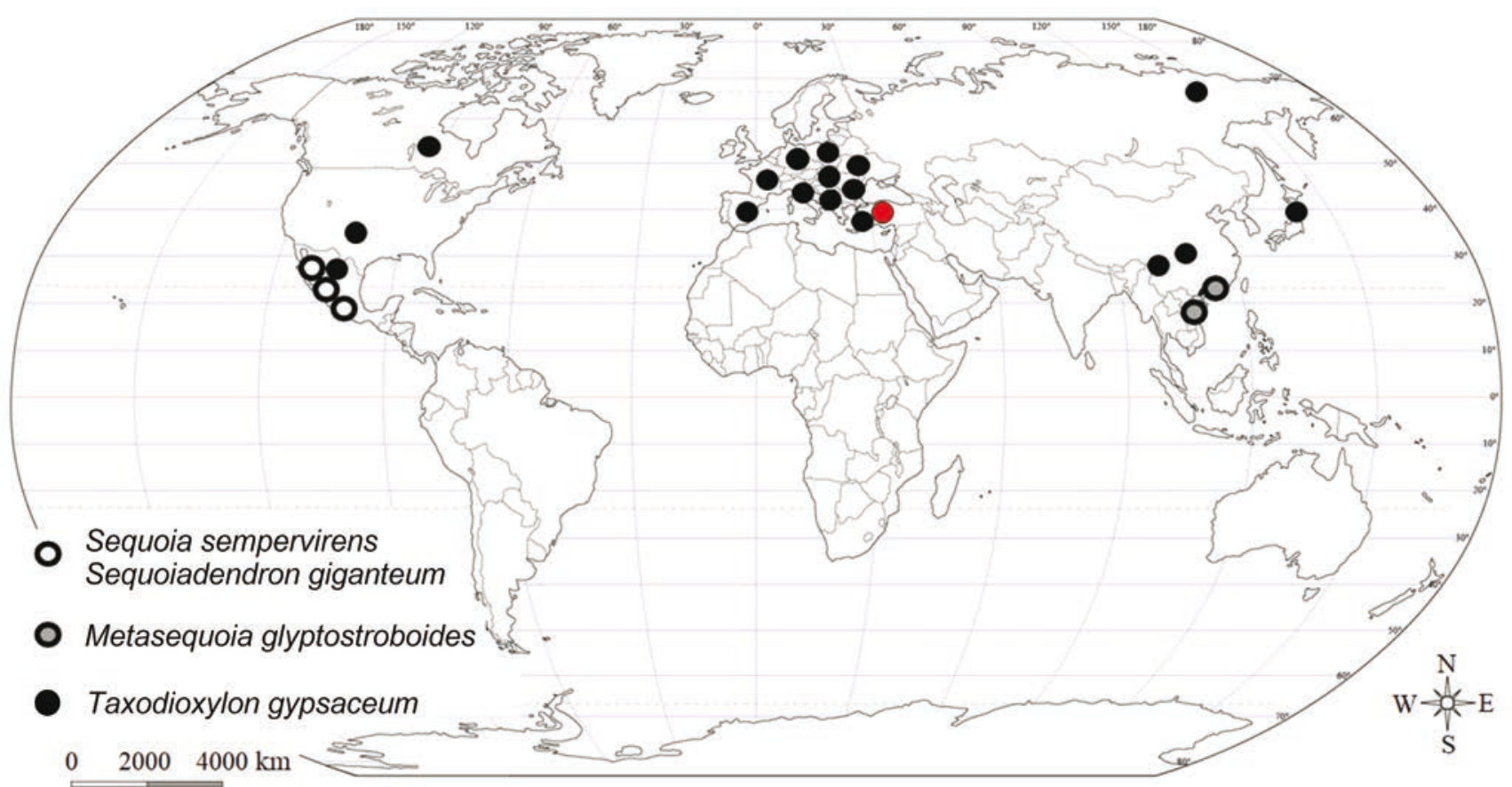

Text-fig. 5. Distribution of Taxodioxylon gypsaceum in the Miocene (solid circles) and distribution (open circles) of its nearest representatives at present (Sequoia sempervirens, Sequoiadendron giganteum and Metasequoia glyptostroboides) (Eckenwalder 2009, Farjon 2010).

Blokhina et al. (2010) stated that the classification of these types of fossil woods is open to discussion. Some authors use "Taxodioxylon" and others "Sequoioxylon". The name Taxodioxylon was used first by Hartig (1848) and was proposed for all woods of the tribe Sequoieae (Sequoia EndL., Sequoiadendron J.BuchHolz and Metasequoia $\mathrm{Hu}$ et W.C.Cheng), Taxodieae (Taxodium Rich.), and Cunninghamieae (Athrotaxis D.Don.). Subsequently, some authors used generic names (e.g. Biondi and Brugiapaglia 1991, Süss and Velitzelos 1997, Erdei et al. 2009). Alternatively, other authors (e.g. Greguss 1967, Basinger 1981, Özgüven-Ertan 1983, Blokhina 1986, 1997, Blokhina and Nassichuk 2000, Akkemik et al. 2005, 2009, Blokhina et al. 2010, Akkemik and Sakınç 2013) used the name Sequoioxylon only for the fossil wood showing affinity to the members of Sequoieae (Sequoia, Sequoiadendron and Metasequoia). Recently, Tian et al. (2018) again discussed taxodioid wood and suggested that the genus Sequoioxylon had been used for fossil woods showing wood anatomical characters of the modern representatives of Sequoioideae with traumatic resin canals, and Taxodioxylon for fossil woods without traumatic resin canals. In the light of this discussion, and the combination of the features given for these two fossil genera, we can consider our woods as Taxodioxylon.

The most common fossil species of Taxodioxylon is $T$. gypsaceum. In this fossil species, growth rings are generally variable, tracheids angular in cross-section, wide in earlywood, narrow in latewood, bordered pits 1-3 seriate, 15-20 $\mu \mathrm{m}$ in diameter, crassulae present, axial parenchyma abundant, horizontal walls of axial parenchyma smooth, rays uniseriate, up to 35 cells in height, cross-field pits predominantly taxodioid (Van der Burgh and Meijer 1996, Koutecký and Sakala 2015). In contrast, T. taxodii GotHAN has typical nodular thickening in the axial parenchyma transverse walls. Yang and Zheng (2003) stated that T. szei YANG et ZHENG had ray tracheids, nodular transverse walls in the axial parenchyma, and higher rays. Blokhina et al. (2010) commented on the absence of vertical traumatic resin canals, and presence of taxodioid type only, and larger number of cross-field pits, and 1-3 seriate tracheidal pitting in T. sizimanicum BloKHINA. Blokhiana et al. (2010) summarized the features of Sequoioxylon laramense R.E.TorR., $S$. montanense R.E.TorR., $S$. dakotense R.E.TorR. and S. burgessii (PENH.) R.E.Torr. They have ray tracheids, nodular transverse walls in the axial parenchyma, very high rays with continuous biseriate ranges. Erdei et al. (2009) identified T. germanicum (Greguss) BuRgh having 1-3 seriate vertical pits on the tracheid radial wall, the presence of crassulae, pits also recorded on tangential walls of tracheids, many cupressoid pits in cross-fields, uniseriate and occasionally biseriate rays.

The wood characters determined in this study are very similar to the characters of Taxodioxylon gypsaceum. Based on this findings, we considered our woods as T. gypsaceum. Van der Burgh and Meijer (1996) first discussed its possible botanical affinities as Athrotaxis (Sequoia) couttsiae (Heer) Gardner, and later, Teodoridis and Sakala (2008) associated T. gypsaceum with Quasisequoia couttsiae HeER. It is generally associated with recent Sequoia sempervirens ENDL. (e.g. Dolezych 2011) as its nearest living relative (Text-fig. 5).

\section{Forest vegetation of GVP in the late Miocene}

The results suggested that the GVP forest composition underwent a structural change during the Miocene (Tab. 2). In the western GVP a riparian forest composed of Palmae, 
Table 2. Petrified wood identification, including the genera of Glyptostroboxylon and Sequoioxylon, throughout Turkey and petrified wood flora of the Galatean Volcanic Province during the Miocene.

\begin{tabular}{|c|c|c|c|}
\hline $\begin{array}{c}\text { European part of Turkey } \\
\text { (Özgüven 1971, Kayacık et al. 1995, } \\
\text { Akkemik et al. 2005, Sakınç et al. } \\
\text { 2007, Akkemik and Sakınç 2013) }\end{array}$ & $\begin{array}{c}\text { West of GVP } \\
\text { (Akkemik et al. 2016, Bayam et al. } \\
\text { 2018) }\end{array}$ & $\begin{array}{c}\text { Central GVP } \\
\text { (Akkemik et al. 2009, } \\
\text { Akkemik et al. 2017, } \\
\text { Bayam et al. 2018) }\end{array}$ & $\begin{array}{c}\text { East of GVP } \\
\text { (The present study) }\end{array}$ \\
\hline $\begin{array}{l}\text { late Oligocene to } \\
\text { early Miocene }\end{array}$ & \multicolumn{2}{|c|}{ early Miocene } & late Miocene \\
\hline & $\begin{array}{c}\text { early - middle Burdigalian } \\
(20-18 \mathrm{Ma})\end{array}$ & $\begin{array}{c}\text { middle - late Burdigalian } \\
(18-17 \mathrm{Ma})\end{array}$ & $\begin{array}{c}\text { Tortonian } \\
(10-9 \mathrm{Ma})\end{array}$ \\
\hline $\begin{array}{c}\text { Swamp Forest } \\
\text { Sequoia }\end{array}$ & $\begin{array}{c}\text { Riparian Forest } \\
\text { Palmae } \\
\text { Salix } \\
\text { Populus } \\
\text { Liquidambar } \\
\text { Lowland and upland forests } \\
\text { Quercus sect. Ilex } \\
\text { Acer } \\
\text { Fraxinus } \\
\text { Zelkova } \\
\text { Ulmus } \\
\text { Prunus } \\
\text { Juniperus } \\
\text { Pinus } \\
\text { Picea } \\
\text { Cedrus } \\
\text { Podocarpus }\end{array}$ & $\begin{array}{c}\text { Swamp Forest } \\
\text { Glyptostrobus } \\
\text { Taxodium } \\
\text { Sequoia }\end{array}$ & $\begin{array}{l}\text { Swamp Forest } \\
\text { Glyptostrobus } \\
\text { Sequoia }\end{array}$ \\
\hline
\end{tabular}

Salix, Populus and Liquidambar was described from the early - middle Burdigalian. Around this riparian forest Quercus sect. Ilex, Acer, Fraxinus, Zelkova, Ulmus, Prunus, Juniperus, Pinus, Picea, Cedrus and Podocarpus constituted the mesic and mesic-xeric forest vegetation (Akkemik et al. 2016, Bayam et al. 2018). Akkemik et al. (2009, 2017) and Bayam et al. (2018) proposed that the central part of the GVP had a broad riparian/swamp forest area during the middle - late Burdigalian (early Miocene). The present study suggests that this riparian/swamp forest composed of Glyptostroboxylon rudolphii and Taxodioxylon gypsaceum existed also in the late Miocene (during the Tortonian) in a

The eastern part of GVP: The geological age of the area is the late Miocene and forest type is swamp forest composed of Glyptostrobus and Sequoia, and a riparianhumid forest having Sequoia trees. This new forest type is rather similar to the forest type in the middle-late Burdigalian of the central GVP.

b

The central part of GVP: The geological age of the area is the middle-late Burdigalian (early Miocene) and forest type is swamp forest composed of Glyptostrobus,

Taxodium and Sequoia, and riparian-humid forest having Sequoia trees (Akkemik et al. 2009, Akkemik et al. 2017).

\section{C}

The western part of GVP: The geological age of the area is the early-middle Burdigalian and forest type is riparian forest composed of Palmae, Salix, Populus, Liquidambar; humid-xeric forests composed of Acer, Quercus sect. Ilex, Fraxinus, Ulmus, Zelkova, Prunus, and conifer trees composed of Pinus, Picea, Cedrus, Juniperus and Sequoia (Akkemik et al. 2016, Bayam et al. 2018).
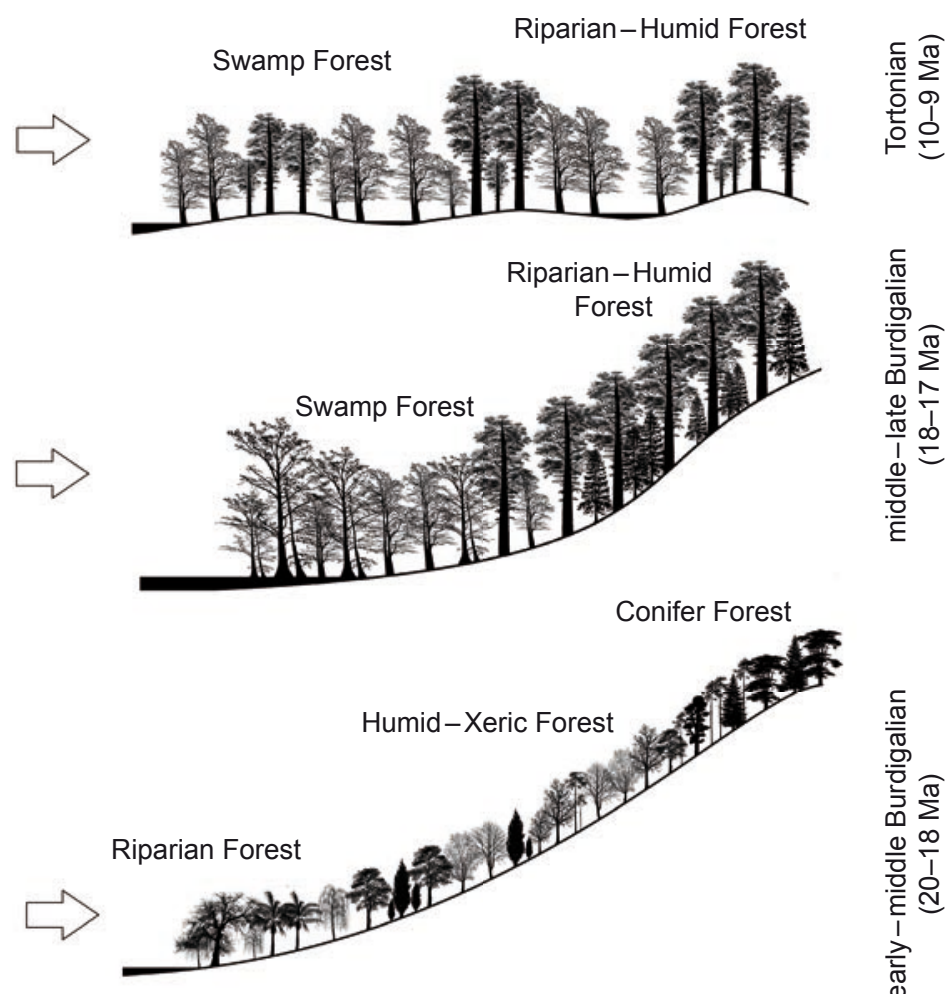

Text-fig. 6. The riparian/swamp forest structure of the village of Sakarcaören in the late Miocene, location within the east part of GVP, and comparison with the other forest types from early Miocene of GVP (Akkemik et al. 2009, 2016, 2017, Bayam et al. 2018). 
the GVP (Text-fig. 6). All former studies in Turkey and its surroundings revealed that these genera (Taxodioxylon and Sequoioxylon) lived during the late Oligocene (ÖzgüvenErtan 1971, Akkemik et al. 2005, Sakınç et al. 2007, Akkemik and Sakınç 2013) and early Miocene (Süss and Velitzelos 1997, Akkemik et al. 2009, Bayam et al. 2018). Our results show that the genera of Glyptostroboxylon, Taxodioxylon and Sequoioxylon had a longer history beginning in the Oligocene and persisting to the late Miocene.

Taxodious woods were identified from the middle to the late Miocene of Romania (Iamandei et al. 2008). Later it was found in Pliocene sediments of Ukraine (Tiemei et al. 2013), Romania (Diaconu 2011) and Spain (Olivares et al. 2004). According to our results, G. rudolphii and T. gypsaceum became extinct in GVP not earlier than the late Miocene.

\section{Climate of GVP in the late Miocene}

The genus Glyptostrobus, which is the modern representative of Glyptostroboxylon rudolphii, is one of the typical components of swamp forests. Today, it has only one species (Glyptostrobus pensilis) (Text-fig. 4) which grows in low, damp, riparian areas and swamps of Vietnam and South China (Eckenwalder 2009, Farjon 2010). These swamp forests exist under warm and subtropical climate conditions. Satchell (1985) suggested that Glyptostrobus forests formed raised swamps in a warm climate with high, nonseasonal rainfall (Text-figs 4, 6).

The genus Sequoia, which is the modern representative of Taxodioxylon gypsaceum, is typical of riparian, well drained and warm to cool conditions. Snyder (1992) suggested that cool, wet winters and warm summer droughts were the climate conditions of the redwood region today, and maritime fog and stratus regimes provide good conditions during dry seasons. The best growing sites of Sequoia are sedimentary soils and riparian areas far from salt sprays of coastlines.

Today, the cold hardiness limit of both genera (Sequoia and Glyptostrobus) is between $-12.1{ }^{\circ} \mathrm{C}$ and $-6.7{ }^{\circ} \mathrm{C}$ (Bannister and Neuner 2001). Snyder (1992) also concluded that Sequoiadendron was restricted to west-central North America in the late Oligocene, and Sequoia had been common through Eurasia up to the end of the Pliocene (Text-fig. 5).

These two wood species grew in swamp forests and the surrounding areas under warm-temperate climate conditions. Numerous palaeobotanical studies (e.g. Akgün et al. 2007, Akkiraz et al. 2011, Velitzelos et al. 2014, Akkemik et al. 2016, Bouchal et al. 2016, 2017, Güner et al. 2017, Denk et al. 2017a, b, c, Bayam et al. 2018) suggested that a subtropical to warm-temperate climate prevailed over large parts of Turkey and Greece during the early Miocene. The present study shows that the identified species lived under similar climate conditions in the late Miocene.

\section{Conclusions}

This study included the first petrified wood identification from the eastern GVP. This volcanic massive was separated into two volcanic phases: 1) early Miocene and 2) late
Miocene. The early Miocene wood flora of the western and central GVP, has provided evidence of taxonomically distinct local associations and further support for the current hypotheses of a warm temperate climate prevailing over a heterogeneous landscape comprising a riverine association, a mesic-xeric woodland association and possibly a mixed coniferous forest in the western area of the GVP, and swamp forest associations located towards the central area of the GVP. The study showed that very similar wood flora and swamp forests in the central GVP continued in the second volcanic phase during the late Miocene of the eastern GVP. These results and discussions may also suggest that new taxodioid type woods might be found from younger geological formations (Pliocene) in Turkey.

\section{Acknowledgements}

This study was supported by the Research Fund of Istanbul University. Project No: 22800. We thank David Simpson for the English editing of the paper, and Res. Ass. Ferdi Akarsu for help with the drawing of some figures.

\section{References}

Adiyaman, Ö., Chorowicz, J., Arnaud, O. C., Gündoğdu, M. N., Gourgaud, A. (2001): Late Cenozoic tectonics and volcanism along the North Anatolian Fault: new structural and geochemical data. - Tectonophysics, 338: $135-165$. https://doi.org/10.1016/S0040-1951(01)00131-7

Akbaş, B., Sevin, M., Aksay, A. (2002): 1/100.000 Scale Geological Map of Turkey No. 40 Bolu - H28 Sections of MTA Geological Survey Department. - MTA Geological Survey Department Ankara, Turkey. (In Turkish)

Akgün, F., Akay, E., Erdoğan, B. (2002): Tertiary terrestrial to shallow marine deposition in central Anatolia: A palynological approach. - Turkish Journal of Earth Science, 11: $127-160$

Akgün, F., Kayseri, M. S., Akkiraz, M. S. (2007): Paleoclimatic evolution and vegetational changes during the Late Oligocene-Miocene period in western and central Anatolia (Turkey). - Palaeogeography, Palaeoclimatology, Palaeoecology, 253: 56-90. https://doi.org/10.1016/j.palaeo.2007.03.034

Akkemik, Ü., Acarca, N. N., Hatipoğlu, M. (2017): The first Glyptostroboxylon from the Miocene of Turkey. - IAWA Journal, 38(4): 561-570. https://doi.org/10.1163/22941932-20170181

Akkemik, Ü., Arslan M., Poole I., Tosun S., Köse N., Karlıŏglu Kılıç, N., Aydın, A. (2016): Silicified woods from two previously undescribed early Miocene forest sites near Seben, northwest Turkey. - Review of Palaeobotany and Palynology, 235: 31-50. https://doi.org/10.1016/j.revpalbo.2016.09.012

Akkemik, Ü., Kıran Yıldırım, D., Sakala, J., Akkılıç, H., Altınış1k, A. (2019): New petrified wood descriptions from west-central Anatolia: contribution to the composition of the Neogene forest of Turkey. - Neues Jahrbuch für Geologie und Paläontologie, Abh., 292(1): 57-71. https://doi.org/10.1127/njgpa/2019/0808 
Akkemik, Ü., Köse, N., Poole, I. (2005): Sequoioidae (Cupressaceae) woods from the upper Oligocene of European Turkey (Thrace). - Phytologia Balcanica, 11(2): 119-131.

Akkemik, Ü., Sakınç, M. (2013): Sequoioxylon petrified woods from the Mid to Late Oligocene of Thrace (Turkey). - IAWA Journal, 34(2): 177-182.

https://doi.org/10.1163/22941932-00000015

Akkemik, Ü., Türkoğlu, N., Poole, I., Çiçek, I., Köse, N., Gürgen, G. (2009): Woods of a Miocene petrified forest near Ankara, Turkey. - Turkish Journal of Agriculture and Forestry, 33: 89-97.

Akkiraz, M. S., Akgün, F., Utescher, T., Bruch, A. A., Mosbrugger, V. (2011): Precipitation gradients during the Miocene in Western and Central Turkey as quantified from pollen data. - Palaeogeography, Palaeoclimatology, Palaeoecology, 304: 276-290.

https://doi.org/10.1016/j.palaeo.2010.05.002

Altun, İ. E., Kadınkız, G., Aksay, A. (2002): 1/100.000 Scale Geological Map of Turkey No. 41 Bolu - H28 Sections of MTA Geological Survey Department. - MTA Geological Survey Department Ankara, Turkey. (In Turkish)

Bannister, P., Neuner, G. (2001): Frost resistance and the distribution of conifers. - In: Bigras, F. J., Colombo, S. J. (eds), Conifer cold hardiness. Kluwer Academic Publishers, Dordrecht, pp. 3-22. https://doi.org/10.1007/978-94-015-9650-3_1

Barefoot, A. C., Hankins, F. W. (1982): Identification of Modern and Tertiary Woods. - Clarendon Press, Oxford, 189 pp.

Basinger, J. F. (1981): The vegetative body of Metasequoia milleri from the Middle Eocene of southern British Columbia. - Canadian Journal of Botany, 59(12): 2379-2410. https://doi.org/10.1139/b81-291

Bayam, N. N. A., Akkemik, Ü., Poole, I., Akarsu, F. (2018): Further Contributions to the early Miocene forest vegetation of the Galatean Volcanic Province, Turkey. - Palaeontologia Electronica, 21.3.40A: 1-42.

https://doi.org/10.26879/816

Biondi, E., Brugiapaglia, E. (1991): Taxodioxylon gypsaceum in the fossil forest of Dunarobba (Umbria, Central Italy). - Flora Mediterranea, 1: 111-120.

Blokhina, N. I. (1986): Sequoia Wood from the Late Oligocene of Siziman Bay (Khabarovsk Region). - Paleontological Journal, 3: 131-135.

Blokhina, N. I. (1997): Fossil Wood of Sequoioxylon chemrylicum sp. nov. (Taxodiaceae) from the Paleogene of Chemurnaut Bay, Kamchatka. - Paleontological Journal, 31(2): 235-238. https://doi.org/10.1134/S0031030110100011

Blokhina, N. I., Afonin, M. A., Kodrul, T. M. (2010): Fossil Wood of Sequoioxylon burejense sp. nov. (Taxodiaceae) from the Upper Cretaceous of the Zeya-Bureya Basin (Russian Far East). - Paleontological Journal, 44(10): 1231-1239.

Blokhina, N. I., Nassichuk, W. W. (2000): Lower Tertiary Wood of Sequoioxylon canadense sp. nov. (Taxodiaceae) from a Kimberlite Pipe (Northern Canada). - Paleontological Journal, 85(4), 122-132.

Bouchal, J. M., Grímsson, F., Zetter, R., Denk, T. (2016): The middle Miocene palynoflora and palaeoenvironments of Eskihisar (Yatağan Basin, southwestern Anatolia): a combined LM and SEM investigation. - Botanical Journal of Linnaean Society, 182: 14-79.

https://doi.org/10.1111/boj.12446

Bouchal, J. M., Mayda, S., Akgün, F., Grímsson, F., Zetter, R., Denk, T. (2017): Miocene palynofloras of the Tinaz lignite mine, Muğla, southwest Anatolia: taxonomy, palaeoecology and local vegetation change. - Review of Palaeobotany and Palynology, 243: 1-36. https://doi.org/10.1016/j.revpalbo.2017.02.010

Denk, T., Grimm, G. W., Manos, P. S., Deng, M., Hipp, A. (2017a): An updated infrageneric classification of the oaks: review of previous taxonomic schemes and synthesis of evolutionary patterns. - In: Gil-Peregrin, E., Peguero-Pina, J. J., Sancho-Knapik, D. (eds), Oaks Physiological Ecology. Exploring the Functional Diversity of Genus Quercus (Tree Physiology 7). Springer Nature, Cham, pp.13-38. https://doi.org/10.1007/978-3-319-69099-5_2

Denk, T., Güner, T. H., Kvaček, Z., Bouchal, M. J. (2017b): The early Miocene flora of Güvem (Central Anatolia, Turkey): a window into early Neogene vegetation and environments in the Eastern Mediterranean. - Acta Palaeobotanica, 57: 237-338.

https://doi.org/10.1515/acpa-2017-0011

Denk, T., Velitzelos, D., Güner, T., Bouchal, J. M., Grimsson, F., Grimm, G. W. (2017c): Taxonomy and palaeoecology of two widespread western Eurasian Neogene sclerophyllous oak species: Quercus drymeja Unger and Q. mediterranea Unger. - Review of Palaeobotany and Palynology, 241: 98-128. https://doi.org/10.1016/j.revpalbo.2017.01.005

Diaconu, F. (2011): The paleoecology analysis of Mio-Pliocene flora in Mehedinti District, Romania. - In: Csiki, Z., (ed.), Abstract Book, Eighth Romanian Symposium on Paleontology, September 29th-30th, 2011, Bucharest, Romania, pp. 35-36.

Dolezych, M., Van der Burgh, J. (2004): Xylotomische Untersuchungen an inkohlten Hölzern aus dem Braunkohlentagebau Berzdorf (Oberlausitz, Deutschland). Feddes Reportorium, 115(5-6): 397-437. https://doi.org/10.1002/fedr.200411044

Dolezych, M. (2011): Taxodiaceous woods in Lusatia (Central Europe), including curiosities in their nomenclature and taxonomy, with a focus on Taxodioxylon. - Japanese Journal of Historical Botany, 19(1-2): 25-46.

Eckenwalder, J. E. (2009): Conifers of the World. - Timber Press, Portland, OR, 744 pp.

Erdei, B., Dolezych, M., Hably, L. (2009): The buried Miocene forest at Bükkábrány, Hungary. - Review of Palaeobotany and Palynology, 155(1-2): 69-79. https://doi.org/10.1016/j.revpalbo.2009.01.003

Fairon-Demaret, M., Steurbaut, E., Damblon, F., Dupuis, C., Smith, T., Gerrienne, P. (2003): The in situ Glyptostroboxylon forest of Hoegaarden (Belgium) at the Initial Eocene Thermal Maximum (55 Ma). - Review of Palaeobotany and Palynology, 126: 103-129. https://doi.org/10.1016/S0034-6667(03)00062-9

Farjon, A. (2010): A Handbook of the World's Conifers, vols 1+2. - Brill Academic Publishers, Leiden and Boston, $1111 \mathrm{pp}$.

Gothan, W. (1905): Zur Anatomie lebender und fossiler Gymnospermen Hölzer. - Abhandlungen der Königlich 
Preussischen Geologischen Landesanstalt, Neue Folge, 44: $1-108$.

Greguss, P. (1967): Fossil Gymnosperm Woods in Hungary, From Permian to Pliocene. - Akadémia Kiadó, Budapest, $136 \mathrm{pp} .+86 \mathrm{pls}$.

Güner, H. T., Bouchal, J. M., Köse, N., Göktaş, F., Mayda, S., Denk, T. (2017): Landscape heterogeneity in the Yatağan Basin (southwestern Turkey) during the middle Miocene inferred from plant macrofossils. - Palaeontographica, Abt. B, 296(1-6): 113-171. https://doi.org/10.1127/palb/296/2017/113

Hartig, T. (1848): Beiträge zur Geschichte der Pflanzen und zur Kenntnis der norddeutschen Braunkohlen-Flora. Botanisches Zeitung, 6: 122-128, 137-141, 166-172, 185-190.

Iamandei, S., Iamandei, E., Sabou-Dumitrescu, M. (2013): New petrified woods from Căprioara Valley, Feleacu Hill, Cluj, Romania. - Romanian Journal of Earth Sciences - RJES, 8(1): 1-27.

Iamandei, S., Iamandei, E., Ionesi, V. (2008): New petrified woods within Sarmatian Şomuz Formation, NE Romania. - Acta Palaentologica Romania, 6: 137-144.

IAWA Committee (2004): IAWA list of microscopic features for softwood identification. - IAWA Journal, 25: 1-70. https://doi.org/10.1163/22941932-90000349

Karayiğit, A. I., Akgün, F., Gayer, R. A., Temel, A. (1999): Quality, palynology, and palaeoenvironmental interpretation of the Ilgın lignite, Turkey. - International Journal of Coal Geology, 38: 219-236. https://doi.org/10.1016/S0166-5162(98)00015-9

Kasapligil, B. (1977): A late Tertiary conifer-hardwood forest from the vicinity of Güvem village, near Kızılcahaman, Ankara. - Bulletin of Mineral Research and Exploration Institute of Turkey, 88: 94-102.

Kayseri, M. S., Akgün, F. (2008): Palynostratigraphic, palaeovegetational and palaeoclimatic investigations on the Miocene deposits in Central Anatolia (Çorum Region and Sivas Basin). - Turkish Journal of Earth Science, 17: 361-403.

Kazanc1, N. (2012): Geological background and three vulnerable geosites of Kızılcahamam-Çamlıdere Project in Ankara, Turkey. - Geoheritage, 4: 249-261. https://doi.org/10.1007/s12371-012-0064-2

Keller, J., Jung, D., Eckhardt, F. J., Kreuzer, H. (1992): Radiometric ages and chemical characterization of the Galatean Andesite Massif, Pontus, Turkey. - Acta Vulcanologica, 2: 267-276.

Koçyiğit, A., Winchester, J. A., Bozkurt, E., Holland, G. (2003): Sarackoy volcanic suite: implications for the subductional phase of arc evolution in the Galatean arc complex, Ankara, Turkey. - Geological Journal, 38: $1-14$. https://doi.org/10.1002/gj.921

Koutecký, V., Sakala, J. (2015): New fossil woods from the Paleogene of Doupovské hory and České středohoří Mts. (Bohemian Massif, Czech Republic). - Acta Musei Nationalis Pragae, Series B - Historia Naturalis, 71: 377-398.

Olivares, C. A., Anton, M. G., Manzaneque, F. G., Juaristi, C. M. (2004): Palaeoenvironmental interpretation of the Neogene locality Caranceja (Reocín, Cantabria, N Spain) from comparative studies of wood, charcoal, and pollen. - Review of Palaeobotany and Palynology, 132: 133-157.

https://doi.org/10.1016/j.revpalbo.2004.05.004

Özgüven-Ertan, K. (1971): Sur un bois fossile de Taxodiaceae dans la flore Neogene d'Istanbul (Turquie d'Europe): Sequoioxylon egemeni $\mathrm{n}$. sp. - Review of Faculty Science l'Université d'Istanbul, Series B, 36: 89-114.

Özgüven-Ertan, K. (1983): Sequoioxylon gypsaceum (Göppert) Greguss bois fossile du Tertiaire d'Ankara, Beypazarı (Turquie). - İstanbul Üniversitesi Fen Fakültesi mecmuas1, Series B, 46: 21-28.

Pujana, R. R., Ruiz, D. P. (2017): Podocarpoxylon Gothan reviewed in the light of a new species from the Eocene of Patagonia. - IAWA Journal, 38(2): 220-244. https://doi.org/10.1163/22941932-20170169

Sakala, J. (2011): Silicified stem from the Late Eocene fossil locality of Kučlín (Czech Republic): overview and new remarks. - Acta Musei Nationalis Pragae, Series B - Historia Naturalis, 67(3-4): 145-148.

Sakınç, M., Aras, A., Yaltırak, C., Batı, Z., Çağatay, N. (2007): Trakya Karasal Tersiyerinde Silisleşmiş Ağaçlar, Paleoflora, Paleoklimatoloji, Paleocoğrafya [Silicified trees in Tertiary of Thrace: Paleoflora, Paleoclimatology, Paleogeography]. - Scientific and Technical Research Council of Turkey, Project Number: 103Y137. (in Turkish)

Satchell, L. S. (1985): Climate and depositional environment of Glyptostrobus forest swamps that formed thick low-ash coals in the Paleocene Powder River Basin. - In: $2^{\text {nd }}$ Annual Meeting Abstracts, The Society for Organic Petrology (TSOP), p. 11.

Sen, S., Delfino, M., Kazancı, N. (2017): Çeştepe, a new early Pliocene vertebrate locality in Central Anatolia and its stratigraphic context. - Annales de Paléontologie, 103: 149-163. https://doi.org/10.1016/j.annpal.2017.01.004

Sengüler, I. (2007): Orta-Şabanözü (Çankırı) Yöresinin Jeolojisi ve Kömür Potansiyeli [Geology and coal potential of Orta-Şabanözü (Çankırı)]. - Bulletin of Mineral Research and Exploration Institute of Turkey, 31(1): 15-24. (in Turkish)

Sevin, M., Uğuz, M. F. (2011): Geology map of the Çankırı Quadrangle. - General Directorate of Mineral Research and Exploration, Ankara.

Snyder, J. A. (1992): The ecology of Sequoia sempervirens: An Addendum to "On the edge: Nature's last stand for coast redwoods"; Master thesis. - MS, Faculty of the Department of Biological Sciences, San Jose State University, San Jose, CA, USA. (copy available on-line)

Süss, H., Velitzelos, E. (1997): Fossile Hölzer der Familie Taxodiaceae aus tertiären Schichten des Versteinerten Waldes von Lesbos. Griechenland. - Feddes Repertorium, 108: 1-30. https://doi.org/10.1002/fedr.19971080102

Teodoridis, V., Sakala, J. (2008): Early Miocene conifer macrofossils from the Most Basin (Czech Republic). Neues Jahrbuch für Geologie und Paläontologie, Abh., 250(3): 287-312. https://doi.org/10.1127/0077-7749/2008/0250-0287

Tian, N., Zhu, Z., Wang, Y., Philippe, M., Chou, C., Xie, A. (2018): Sequoioxylon zhangii sp. nov. (Sequoioideae, 
Cupressaceae s.1.), a new coniferous wood from the Upper Cretaceous in Heilongjiang Province, Northeast China. Review of Palaeobotany and Palynology, 257: 85-94. https://doi.org/10.1016/j.revpalbo.2018.07.008

Tidwell, W. D. (1998): Common fossil plants of Western North America. - Smithsonian Institution Press, Washington and London, 299 pp.

Tiemei, Y., Chengsen, L., Syabryaj, S. (2013): Pliocene taxodiaceous fossil wood from southwestern Ukraine and its palaeoenvironmental implications. - Journal of Palaeogeography, 2(4): 362-368. https://doi.org/10.3724/SP.J.1261.2013.00036

Toprak, V., Savasçın, Y., Güleç N., Tankut, A. (1996): Structure of the Galatia volcanic province. - International Geology Review, 38: 747-758. https://doi.org/10.1080/00206819709465358

Türkecan, A., Dinçel, A., Hepşen, N., Papak, İ., Akbaş, B., Sevin, M., Özgür, İ. B., Bedi, Y., Mutlu, G., Sevin, D., Ünay, E., Saraç, G., Karataş, S. (1991): Bolu-Çankırı (Köroğlu Dağlan) arasındaki Neojen yaşlı volkanitlerin stratigrafisi ve petrolojisi [Stratigraphy and petrology of Neogene aged volcanics between Bolu-Çankırı (Köroğlu Mountains)]. - Türkiye Jeoloji Kurultay Bülteni, 6: 85103. (in Turkish)

Uhl, D., Dolezych, M., Böhme, M. (2014): Taxodioxylon-like charcoal from the Late Miocene of western Bulgaria. - Acta Palaeobotanica, 54(1): 101-111. https://doi.org/10.2478/acpa-2014-0004

Van der Burgh, J., Meijer, J. J. F. (1996): Taxodioxylon gypsaceum and its botanical affinities. - Current Science, 70(5): 373-378.

Vassio, E., Martinetto, E., Dolezych, M., Van der Burgh, J. (2008): Wood anatomy of the Glyptostrobus europeus "whole-plant" from a Pliocene forest of Italy. - Review of Palaeobotany and Palynology, 151: 81-89. https://doi.org/10.1016/j.revpalbo.2008.02.006

Velitzelos, D., Bouchal, J. M., Denk, T. (2014): Review of the Cenozoic floras and vegetation of Greece. - Review of Palaeobotany and Palynology, 204: 56-117.

Wheeler, E. A. (2011): InsideWood - a web resource for hardwood anatomy. - IAWA Journal, 32(2): 199-211. https://doi.org/10.1163/22941932-90000051

Wilson, M., Tankut, A., Güleç, N. (1997): Tertiary volcanism of the Galatia Province, NW Central Anatolia, Turkey. - Lithos, 42: 105-121.

https://doi.org/10.1016/S0024-4937(97)00039-X

Yang, X. J., Zheng, S. L. (2003): A new species of Taxodioxylon from the Lower Cretaceous of the Jixi Basin, Eastern Heilongjiang, China. - Cretaceous Research, 24(6): 653-660. https://doi.org/10.1016/j.cretres.2003.07.003

Yavuz-Iş1k, N. (2008): Vegetational and climatic investigations in the Early Miocene lacustrine deposits of the Güvem Basin (Galatean Volcanic Province), NW Central Anatolia, Turkey. - Review of Palaeobotany and Palynology, 150(1-4): 130-139.

https://doi.org/10.1016/j.revpalbo.2008.02.001

Yavuz-Işık, N., Demirci, C. (2009): Miocene spores and pollen from Pelitçik Basin, Turkey - environmental and climatic implications. - Comptes Rendus Palevol, 8(5): 437-446. https://doi.org/10.1016/j.crpv.2009.02.002

\section{Explanations to the plates}

\section{PLATE 1}

Wood features of Glyptostroboxylon rudolphii (SAK18)

1. TS showing indistinct growth ring boundaries marked by $1-2$ indistinct rows of radially flattened latewood tracheids (arrows).

2. TLS showing partly biseriate ray (arrow).

3. Uniseriate rays of 1-4 cell rows in height.

4. Smooth thin end wall of an axial parenchyma cell (arrow).

5. RLS showing the radial surface of tracheids (arrows) with abundant bordered pits, up to 3 rows.

6.-7. Mostly glyptostroboid type cross-field pits (arrow) together with taxodioid types.

\section{PLATE 2}

Wood features of Taxodioxylon gypsaceum (Fig. 2 is SAK12, the others are SAK15)

1.-2. TS showing growth rings with distinct boundaries and abrupt earlywood/latewood transition, and having 2-13 rows of latewood zone.

3. TLS showing uniseriate rays (up to 32 cells in height).

4.-5. TLS axial parenchyma cells with smooth (4) and slightly nodular (5) transverse wall (arrows).

6. RLS with smooth horizontal and end walls of ray cells (arrow).

7. Crassulae and biseriate pitting (RLS) (arrow).

8. Rays with taxodioid type cross-field pits in one horizontal row (RLS) (arrow).

9. RLS showing up to 3 rows of bordered pits on the radial surface of tracheids (arrow). 
PLATE 1
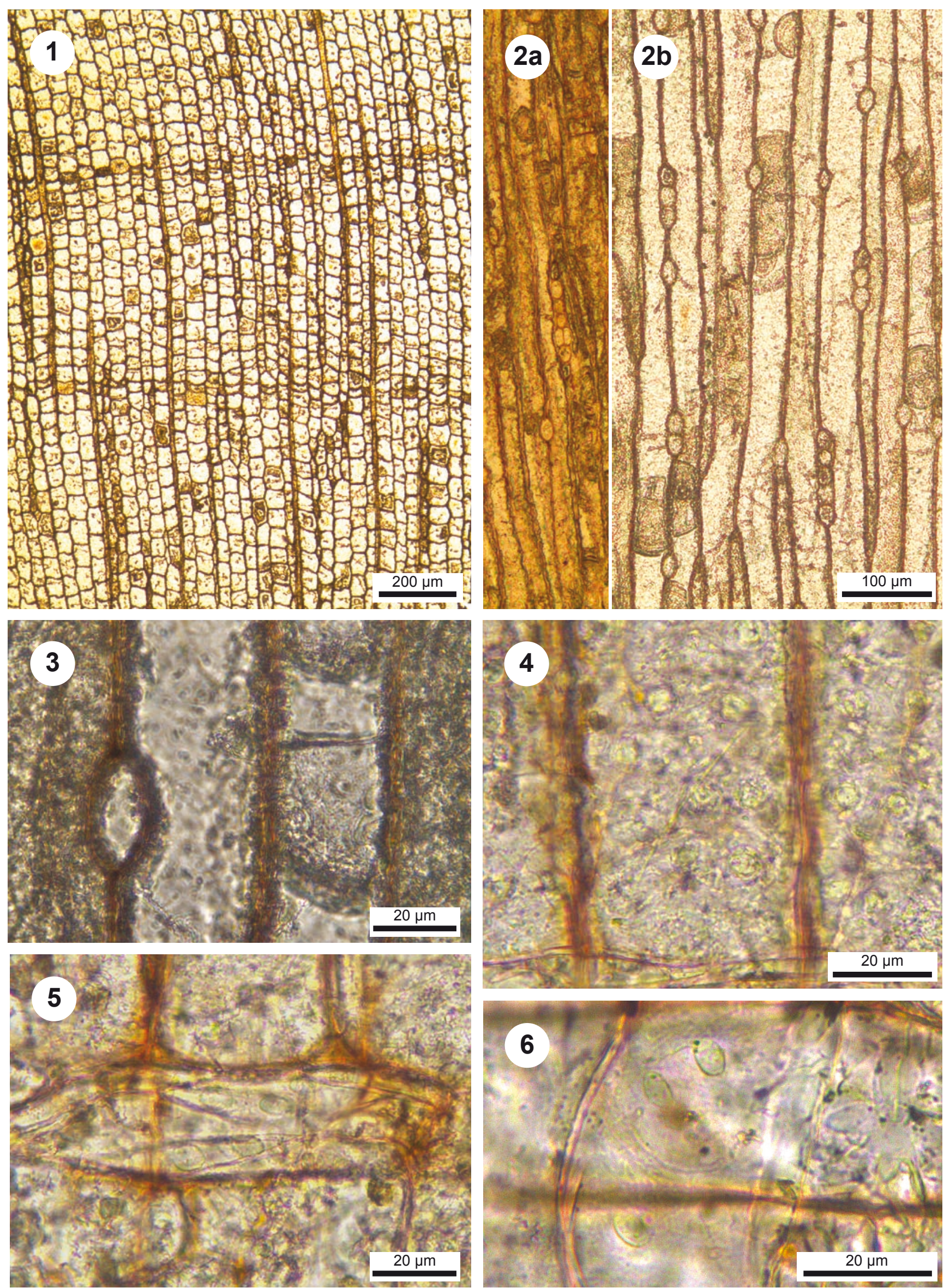


\section{PLATE 2}

1960 907 7 7 7

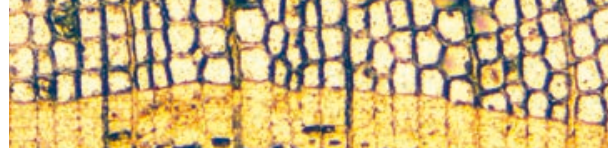

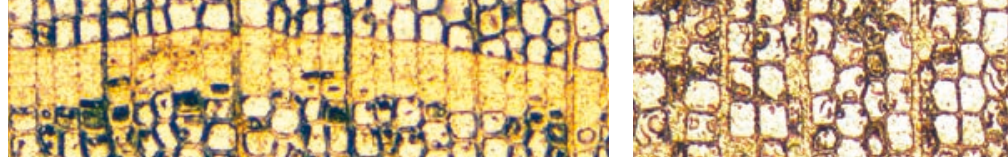
(7)

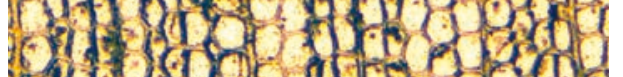
92. ch 120 m $1 \times 10$ Hos

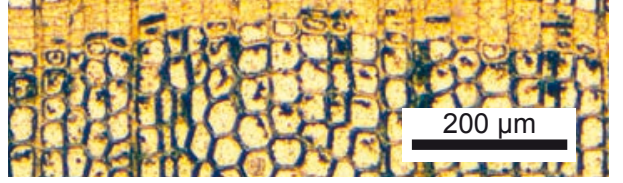
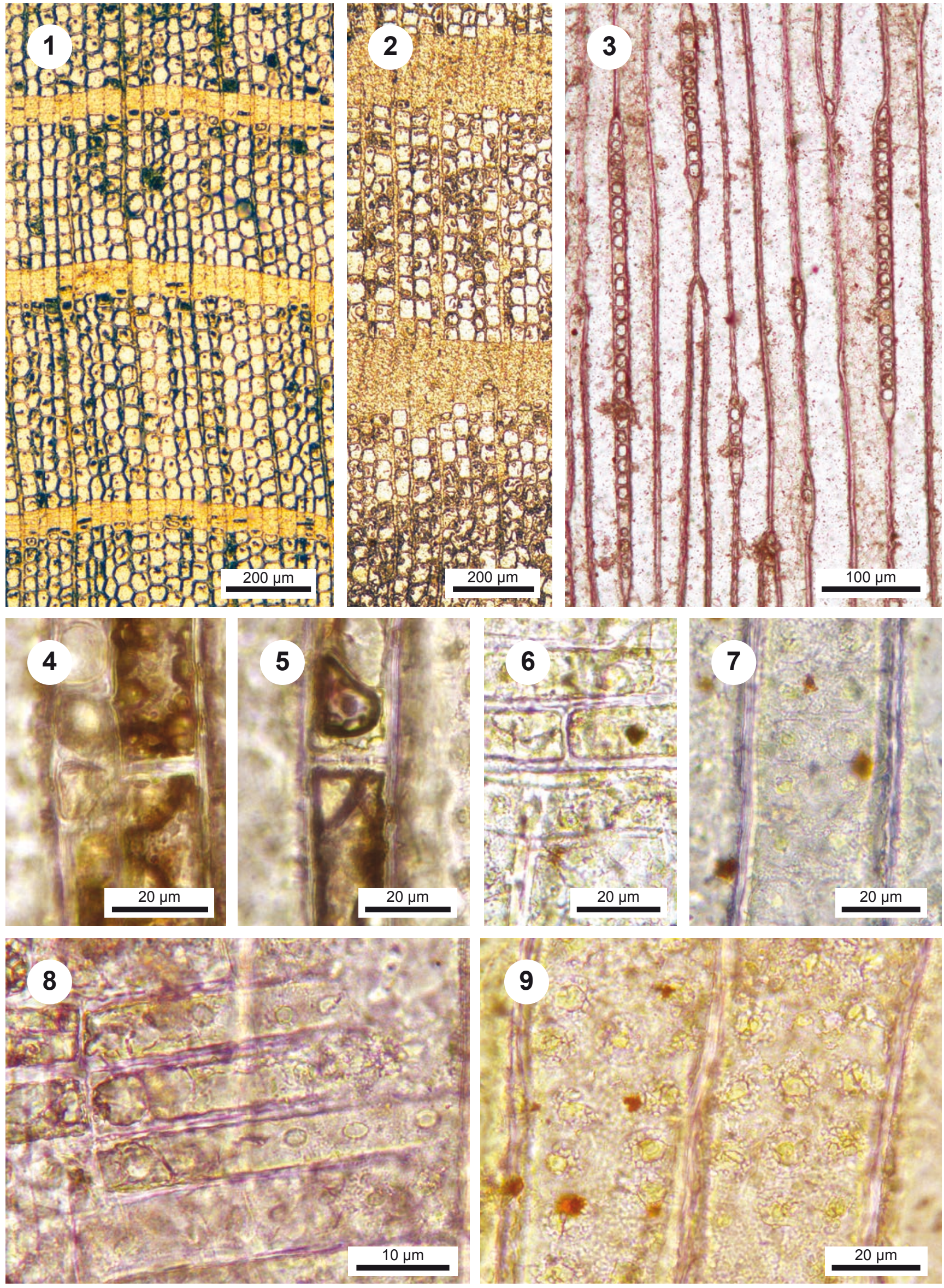